\title{
Recent advances in textile wastewater treatment using microbial consortia
}

\begin{abstract}
The textile wastewaters (TWWs) are one of the major sources of environmental pollution, due to the presence of various recalcitrant dyes. It is estimated that about $300,000 \mathrm{t}$ of synthetic dyes are discharged in TWWs every year worldwide. Thus, untreated or incompletely treated TWWs cause harm to aquatic and terrestrial life. To avoid the negative impacts associated to the discharge of TWWs into the natural ecosystems, effective dye remediation processes are being developed. Current methods of removing dyes from TWWs are generally regarded to be complex, expensive and energy demanding processes. Therefore, bioremediation of TWWs using microbial consortia has appeared as an emerging alternative for textile dyes removal. This chapter provides an updated literature on the application of microbial consortia in the treatment of TWWs, focusing on the mechanisms involved in dye biodegradation and the main interactions established between the consortia members and how they can influence dye removal efficiencies.
\end{abstract}

Keywords: textile wastewaters, bioremediation, co-cultivated microorganisms, azodyes
Volume 5 Issue 3 - 2019

\author{
Imtinen Sghaier, ${ }^{1,2}$ Marwa Guembri, ${ }^{2}$ Habib \\ Chouchane,' Amor Mosbah,' Hadda ' \\ Ouzari, ${ }^{2}$ Atef Jaouani, ${ }^{2}$ Ameur Cherif,' \\ Mohamed Neifar' \\ 'University of Manouba, ISBST, BVBGR-LRI IES3I, Biotechpole \\ of SidiThabet, Ariana, Tunisia \\ ${ }^{2}$ Laboratory of Microorganisms and Active Biomolecules, MBA- \\ LR03ES03, Faculty of Sciences of Tunis, University of Tunis EI \\ Manar,Tunis, Tunisia
}

Correspondence: Mohamed Neifar, University of Manouba, ISBST, BVBGR-LR I IES3 I, Biotechpole of SidiThabet, Ariana,

Tunisia, Email mohamed.naifar@gmail.com

Received: April 23, 2019 | Published: May 10, 2019

\section{Introduction}

During the past few decades, water resources are getting scarcer due to exponential increase in population, agriculture, urbanization and industrialization. ${ }^{1-4}$ Different industrial sectors entail significant environmental and public health concerns. One such industry is textile dyeing which is one of the most water-intensive industries and generates releases consisting of recalcitrant organic molecules generally, problems of color, high concentrations of Biological Oxygen Demand (BOD), Chemical Oxygen Demand (COD), fibers, surfactants, detergents and solvents. ${ }^{5}$ Textile industries consume huge volumes of freshwater for its various wet processes and release equal amounts of wastewaters. ${ }^{6}$ During the dyeing process, not all the dyes are fixed to the fabrics. There is always a portion of unfixed dye which is discharged into the wastewater that forms the major pollutant in this effluent. Textile market utilize more than half of world dye and organic pigment, and the demand is expected to increase more than $\$ 30$ billion in 2019. ${ }^{7}$ Different types of dyes are used in textile industries, the most commonly frequent dyes applied in dyeing units are azo dyes. Apart from textile industry, they are also used in tannery, paper and pulp, pharmaceutical, food, paint, plastics, cosmetics and electroplating industries. ${ }^{8}$ The improper discharge of colored dye effluents into natural water bodies severely affects all living forms and causes aesthetical unpleasantness creating a significant problem to human being. ${ }^{9,10}$ Removal of dyes from effluent has been given a top priority. Several physico-chemical methods have been employed but they have facing several problems, such as generation of toxic by-products and economical unfeasibility. ${ }^{10,11}$ Bioremediation has become a very special challenge since it is cost-effective, eco-friendly and does not produce a large quantity of sludge. ${ }^{12}$ Several studies have focused on the utilization of pure culture to decolorize synthetic dyes. Due to the chemical complexity of these dyes, it is necessary to develop more efficient microbial processes for decolorization. ${ }^{10}$ Recently, trend is shifting towards use of microbial consortia. Several microbial consortia have been reported for efficient dye removal. ${ }^{13}$ In this study the main aim is to emphasize on the existing literature on microbial decolorization of TWWs using co-cultivated microorganisms.

\section{Overview of textile wastewaters and textile dyes}

\section{Characteristics of textile wastewaters}

Textile dyeing industries are facing problems to meet the green practices standards for safe discharge of wastewater due to its complex nature. TWWs are a complex mixture of salts, acids, heavy metals, organ-chlorine-based pesticides, pigments and dyes., ${ }^{5,10}$ TWWs generated from the different wet processes are characterized by high $\mathrm{pH}$, temperature, BOD, COD, detergents, surfactants, suspended and dissolved solids, dispersants, leveling agents, toxic organics, chlorinated compounds, sulphide and formaldehyde, may be added to improve dye adsorption onto the fibers ${ }^{9}$ and more details are mentioned in the Figure 1. Such effluents are also characterized by the presence of heavy metals, such as $\mathrm{Cr}, \mathrm{Zn}, \mathrm{Cu}$ and $\mathrm{Al}$ due to metal-based complexes dyes. ${ }^{10,14}$ The most common textile operates are desizing, bleaching, mercerizing, dyeing and finishing. ${ }^{15}$ Characteristics and the amount of TWWs depend to the process, dyeing is the most one which requires large volumes of water not only in the step of adding color to the fibers, in dye bath, but also during the rinsing step. Mercerizing and finishing are also significant generators of TWWs. In addition, equipment, machines and chemicals, ${ }^{5}$ such as detergents and stabilizers, alter significantly the nature of TWWs. Another important factor which contributes to the ecotoxicity and the volume of TWWs is that dyeing and finishing processes, especially, require the imput of a wide range of dyestuffs. The Variety of dyes depends to the fiber used. ${ }^{16}$ For example, cellulose fiber requires the application of direct, reactive, vat, azo or sulfide dyes. Acid dyes are used essentially for wool and silk. Azo and disperse dyes are applied to the polyester fiber. A large quantity of these dyes is released in the TWWs due to their degree of fixation to fibers. 


\section{Textile dyes and classification}

According to Witt theory, dyes have a chromophore group which imparts color to the dye and auxochromes to intensify the color when introduced into a colored molecule. The most important auxochromes are amine $(-\mathrm{NH} 3)$, carboxyl $(-\mathrm{COOH})$, sulfonate $(-\mathrm{SO} 3 \mathrm{H})$ and hydroxyl $(-\mathrm{OH}) \cdot{ }^{17}$ Based on the method of application, main classes of dyes are: acid, basic, direct, reactive, disperse, vat, mordant and sulphur ${ }^{18,19}$ and according to the chemical structure and the type of the chromophore present in the molecule, the most important classes, as indicated in Table 1, are azo, anthraquinone, nitro and other dyes. Azo dyes account for over $50 \%$ of commercial dyes available in the market and constitute the most important class applied in textile processing industries. ${ }^{14}$ The first azo dye, Aniline Yellow was reported in 1858 by Griss. More than 10,000 dyes are available commercially and more than $7 \times 105$ tons of dyestuffs are produced annually., ${ }^{9,20}$ Azo dyes are characterized by the presence of one or more azo groups (R1$\mathrm{N}=\mathrm{N}-\mathrm{R} 2$ ), the persistence and the stability against microbial attack.

\section{Environmental and health impacts of textile wastewaters}

The release of TWWs causes dark coloration of surface waters that captures the attention of both the public and the authorities. During textile processing, a large amount of dyestuff is liberated directly in the effluent due to inefficiencies in dyeing step. In addition, dyes absorb

Table I Classification of dyes based on the chromophore group light in the visible range, being detectable even at a concentration of $1 \mathrm{ppm} .{ }^{14}$ Apart from the aesthetic unpleasantness, the main environmental concern with the dyes is their absorption and reflection of sunlight penetration, which, in turn, decreases photosynthetic activity and dissolved oxygen amount in the water, and affects aquatic flora and fauna. ${ }^{10,21,22}$ Several reports have indicated that direct and indirect toxic effects of the dyes and TWWs can cause tumors, cancers and allergies in humans..$^{10,23,24}$ Due to their persistence nature, azo dyes have negative impact on the environment in terms of total organic carbon (TOC), COD and BOD. ${ }^{25}$ Many synthetic dyes and their metabolic intermediate products are found to be toxic, mutagenic and carcinogenic. ${ }^{26,27}$ The Major toxic effects of azo dyes are caused by aromatic amines generated after their biodegradation. Also, there are a large group of aromatic amines which are either cancer-suspect agents or established mutagens in the standard Salmonella mutagenicity assay. ${ }^{28}$ Some azo dyes can be carcinogenic without being cleaved into aromatic amines. However, the carcinogenicity of many azo dyes is due to their cleaved product such as benzidine. Benzidine induces different human and animal tumors. Another azo dye component p-phenylenediamine (p-PDA) is a contact allergen. ${ }^{29}$ Reports are also available on other important dyes including triphenylmethane and anthraquinone which have been shown negative impacts. ${ }^{12,30,31}$ Some dyes from the triphenylmethane group have been reported to be toxic, mutagenic, and carcinogenic. ${ }^{30,31}$ More details about impacts of TWWs are indicated in Figure 1.

Class




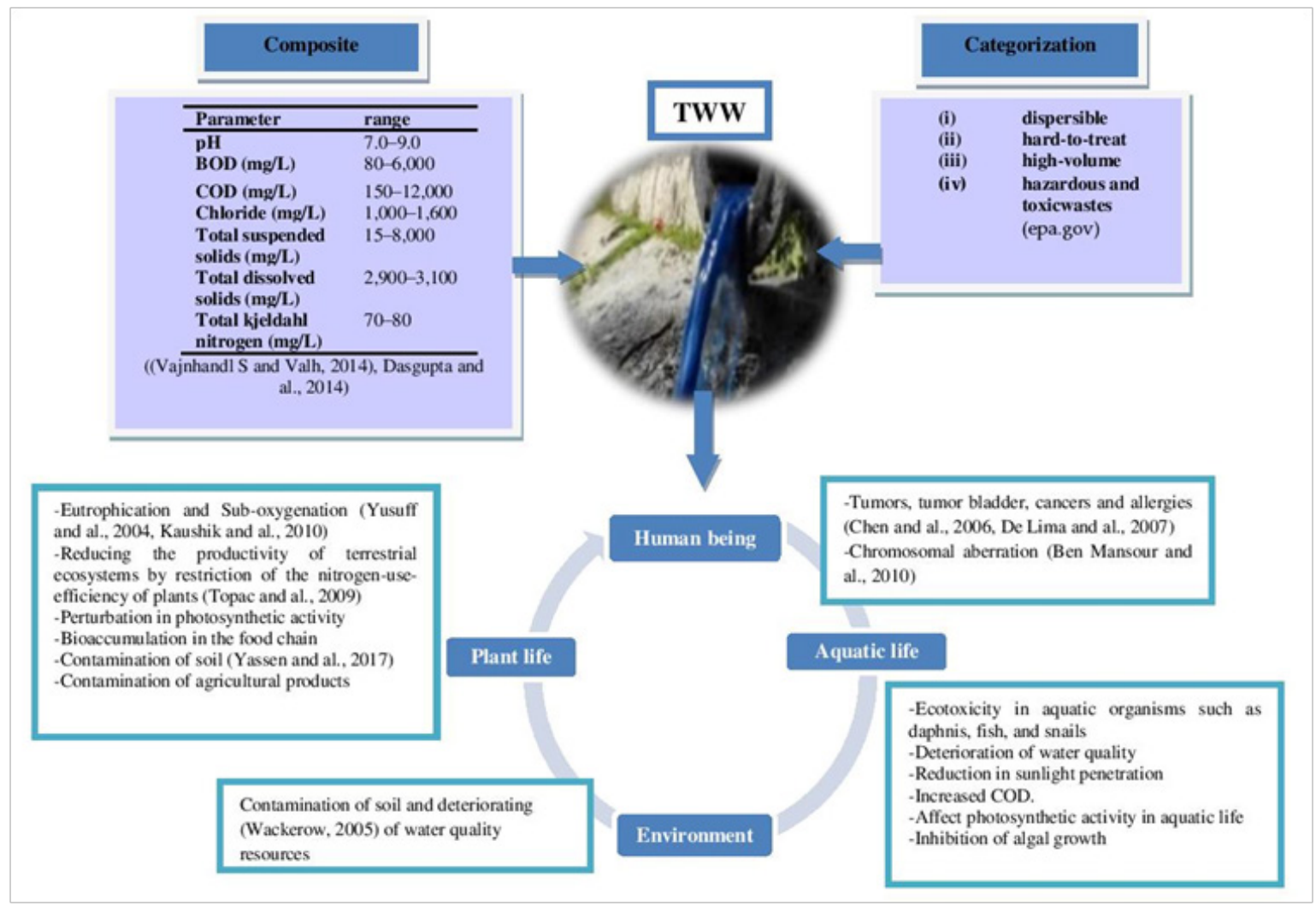

Figure I Overview of textile wastewaters: characteristics and hazards.

\section{Different treatments of textile wastewaters}

Considering the several hazards of dyes, their removal before their discharge into surrounding environment is urgent. So, many technologies have been developed to achieve an efficient and economic treatment. They can be physical, chemical or biological.

\section{Physico-chemical methods}

During the past two decades, several physicochemicaldecolorization techniques, such as coagulation-flocculation, adsorption, oxidation and membrane techniques, have been reported. ${ }^{32}$ Physical methods are mainly used for the primary treatment of TWWs. ${ }^{20}$ Based on coagulation-flocculation of dyes, they are effective for the removal of mainly sulphur and disperse dyes, but show very low capacity for acid, direct, reactive and vat dyes. ${ }^{21}$ Although activated carbon is a very effective adsorbent for various types of dyes, it is not often used due to its high cost and removal $\mathrm{pH}$ dependent but it is capable of treating only small effluent volume, operates at slow speed. ${ }^{33}$ For Chemical treatments, excess use of chemicals requires high cost and results into secondary pollution. ${ }^{34}$ These methods can only transfer the dyestuff from one phase to another leaving the problem essentially unsolved. Briefly, their continuous application put forth their limitations as it is detailed in Figure 2, giving the relay to biological treatment.

\section{Biological treatment}

Biological processes provide an alternative to existing technologies for many purposes (Figure 2). Several microbial sources have been reported including fungi, bacteria, yeasts, algae and actinomycetes. ${ }^{21}$
Extremophilic microorganisms are widely applied in TWWs treatment due to their ability to survive in such harsh condition which poses a limiting factor for mesophilic microorganisms. ${ }^{35,36}$ Plant growth promoting rhizobacteria show also interesting ability to decolorize various textile dyes. ${ }^{37,38}$ These bioprocesses can be classified, on the basis of oxygen requirement, into aerobic, anaerobic and anoxic or facultative or a combination of these. ${ }^{39}$ And they are based on the enzymes synthesized by microorganisms $\mathrm{s}^{40,41}$ or whole cells. The effectiveness of microbial decolorization depends on the adaptability and the activity of selected microorganisms enhanced by its application under optimal conditions. ${ }^{42}$ This decolorization can be achieved through individual and specific strain or co-cultivated microorganisms.

\section{Pure culture}

Bacterial pure culture: There are many published studies dealing with the use of pure cultures in decolorization process (Table 2). Therefore, a large number of microorganisms and enzymes have been isolated. Among these microorganisms, bacteria are frequently used. Attempts to isolate pure bacterial cultures capable of degrading azo dyes started way back in 1970s with isolation of Bacillus subtilis, Aeromonas hydrophila and Bacillus cereus. ${ }^{10,43}$ As reflected in Table 2 , there are other extensive reports describing the decolorization of reactive azo dyes mediated by pure culture. Among these strains, Pseudomonasis largely exploited to decolorize commercial textile azo dyes, such as Remazol Orange 3R by Pseudomonas aeruginosa strain $\mathrm{BCH}$ with removal of $98 \%$ within 15 minutes $^{44}$ or Black B. ${ }^{45}$ Application of the genus Halomonas ${ }^{46,47}$ show also promising results 
azo dye degradation. A.hydrophila and some other aerobic bacteria were studied for azo dye decolorization under aerobic condition by oxygen insensitive or aerobic azoreductases, because azo reductase activity is inhibited in presence of oxygen. ${ }^{48}$

Fungal pure culture: Phanerochaete chrysosporium is the most frequent, robust and model white-rot fungus reported in the literature for decolorizing several dyes from TWWs. ${ }^{49,50}$ Also, three promising strains, Dichomitus squalens, Ischnoderma resinosum and Pleurotus calyptratus show an efficient decolorization of both Orange $G$ and Remazol Brilliant Blue R. ${ }^{51}$ Another white rot fungus Irpex lacteus is capable to decolorize the chromium metal complex dye Isolan Dark Blue 2SGL-01. ${ }^{22}$ In addition, Trametes pubescens was found to be the most effective strain in terms of decolorization performance on the azo dye Congo Red, in submerged culture, ${ }^{53}$ Trametes maxima $\mathrm{CPB} 30^{54}$ and Fomes fomentarius ${ }^{55}$ show an ability to remove Remazol Brilliant Blue R dye. However, degradation of dyes in TWWs by white-rot fungi has some intrinsic drawbacks like the long growth phase and the requirement of nitrogen restrictive environments, unreliable enzyme production and large reactor size due to the long holding time for complete degradation. ${ }^{7,1456}$ Multiple fungal species, particulary the genus Aspergillus described by ${ }^{57}$ are able to decolorize a large number of dyes. This genus was also reported by ${ }^{58}$ Some recent examples are detailed in Table 2.

Yeast pure culture: Yeasts present significant advantages such as low cost, readily availability of biomass source and resistance to extreme environment conditions. Furthermore, several yeasts have been found capable to treat TWWs. ${ }^{59}$ The genus Candida is widely used in dye decolorization and through biodegradation mechanism ${ }^{60-62}$ or biosorption ${ }^{63,64}$ or also by bioaugmentation. ${ }^{65}$ Thermo-tolerant yeast, Kluyveromyces marxianus IMB3C has shown the ability to remove Remazol Black-B. ${ }^{66}$

Importance of treatment with microbial consortium reference to treatment with mono-culture: Due to the limitations of pure strains on decolorization, such as the narrow range for decolorization of different azo dyes and the inability to degrade completely or mineralize these dyes, ${ }^{67}$ it has been observed that microbial consortia are mainly beneficial as they can conjointly carry out degradation tasks that no single culture can begin effectively. ${ }^{14,68-70}$ In addition, reports considered the consortium as a suitable combination of efficient strains which can be used in bioremediation of TWWs providing a rich metabolic network. ${ }^{71}$ In a mixed culture system, the degree of biodegradation and mineralization of dyes is higher due to the synergism of metabolic activities of a microbial community. ${ }^{7,72,73}$ In microbial consortium, the individual strains may attack the dye molecule at different positions or may utilize metabolites produced by the co-existing strains for further decomposition. ${ }^{68}$ In such approaches microbes acclimatize themselves to the toxic wastes and new resistant strains develop naturally, which then transform various toxic chemicals into less harmful forms. ${ }^{19,74}$ The complete degradation of chemical substances is only possible in the presence of several enzymes produced by the mixed cultures. ${ }^{14,75}$ Aromatic amines generated after cleavage of azo bonds are often toxic in nature. But, in a mixed culture, these aromatic amines can be degraded by the synergistic action of organisms. ${ }^{76,77}{ }^{76}$ reported three isolates Micrococcus sp., M. luteus, and P. polymyxa, when used in mixed culture were able to decolorize nine dyes but individually used, they were found to be inefficient for dye removal. ${ }^{14,76}$

Bacterial consortium: Bacterial consortia are the most frequently used for decolorization of azo dyes, as they are generally fast to multiply rapidly under aerobic, anaerobic, facultative conditions as well as in extreme environmental conditions, like high salinity and wide variations in both $\mathrm{pH}$ and temperature. ${ }^{14,22}$ The efficiency of bacterial consortium decolorization compared to pure culture removal is may be due to the involvement of quorum sensing, mechanism by which bacteria regulate gene expression in accordance with population density through the use of signal molecules. Quorum sensing allows bacteria populations to communicate and coordinate group behavior. Recent studies regarding the biodegradation of dyes in TWWs using bacterial consortia are reported in Table 2 . The bacterial decolorization can be directly influenced by various factors ${ }^{78,79}$ such as the level of agitation, oxygen, temperature, $\mathrm{pH}$, dye structure, dye concentration, supplementation of different carbon and nitrogen sources, electron donor, redox mediator ${ }^{80,81}$ and salt concentrations. Therefore, acclimatized bacteria, isolated from dye contaminated sites, are very efficient in removal process due to adaption to different extreme environmental conditions. ${ }^{14}$ Optimization of such abiotic conditions makes the microbial system more efficient and practicable (Table 3).

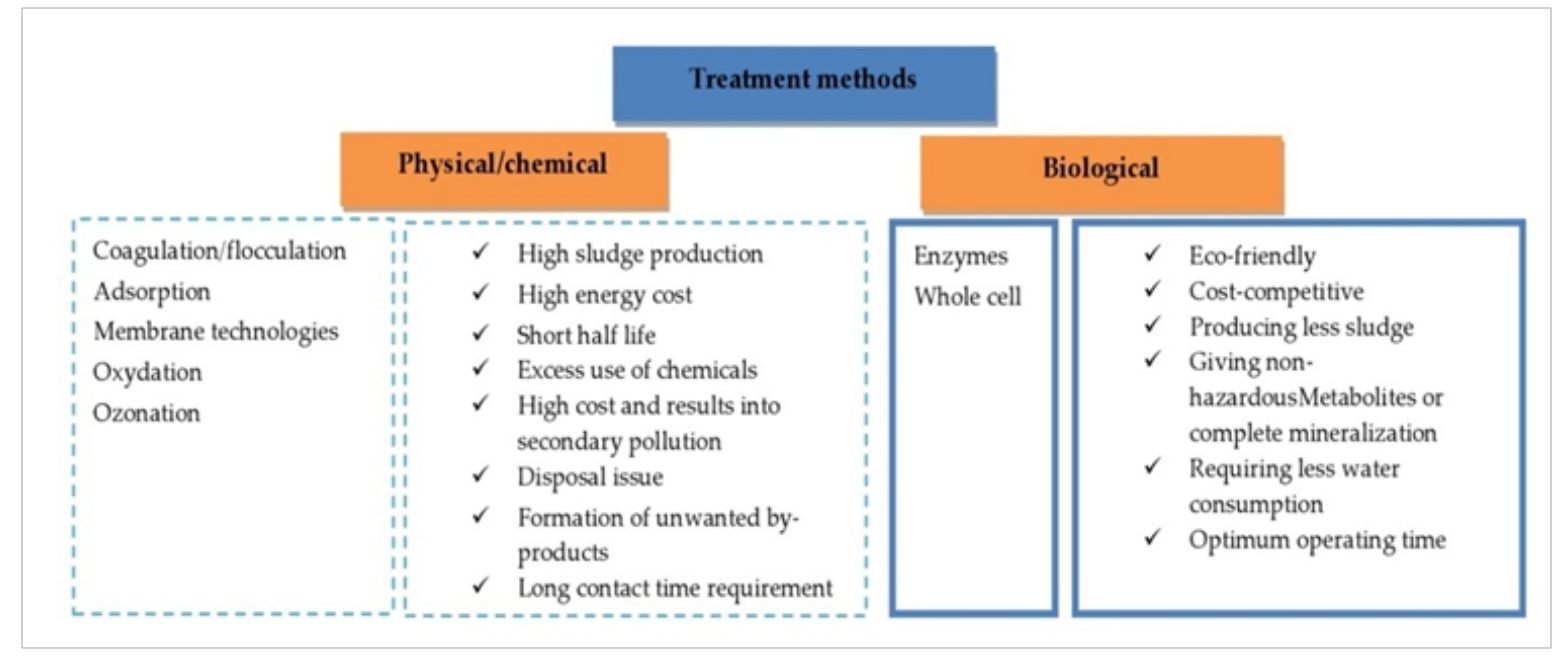

Figure 2 Different treatment methods of textile wastewaters and importance of biological treatment reference to conventional techniques. 
Table 2 Recent reports on microbial pure culture capable of dye degradation

\begin{tabular}{|c|c|c|c|c|c|}
\hline Strain & Dye & $\begin{array}{l}\text { Concentration } \\
(\mathrm{mg} \mathrm{L}-\mathrm{I})\end{array}$ & $\%$ decolorization & Time & References \\
\hline \multicolumn{6}{|l|}{ Yeast culture } \\
\hline Trichosporon beigelii & Navy blue HER & 50 & $95 \%$ & $24 \mathrm{~h}$ & (Dafale et al. ${ }^{25}$ ) \\
\hline Candida krusei & Basic Violet 3 & 10 & $100 \%$ & $24 \mathrm{~h}$ & (Deivasigamani and Das, ${ }^{82}$ ) \\
\hline $\begin{array}{l}\text { Trichosporon akiyoshidainum } \\
\text { HP2023 }\end{array}$ & Reactive Black 5 & 300 & $100 \%$ & $24 \mathrm{~h}$ & (Martorell et al. ${ }^{83}$ ) \\
\hline Candida tropicalis TL-FI & Acid Brilliant Scarlet GR & 100 & $100 \%$ & $24 \mathrm{~h}$ & (Tannadal et al. ${ }^{61}$ ) \\
\hline \multicolumn{6}{|l|}{ Fungal culture } \\
\hline Trichoderma tomentosum & Acid Red $3 \mathrm{R}$ & 85.5 & $99.20 \%$ & $72 \mathrm{~h}$ & $\left(\mathrm{He}\right.$ et $\left.\mathrm{al} .{ }^{84}\right)$ \\
\hline white-rot fungus Cyathus bulleri & Kiton blueA & 50 & $88 \%$ & $6 \mathrm{~h}$ & (Vats and Mishra, ${ }^{85}$ ) \\
\hline Trametes versicolor CBR43 & $\begin{array}{l}\text { acid, disperse and reactive } \\
\text { dyes }\end{array}$ & 200 & $90 \%$ & 9 days & (Yang et al. ${ }^{86}$ ) \\
\hline Bjerkandera adusta OBR I05 & Reactive and acid dyes & 200 & $99 \%$ & 3 days & (Sodaneath et al. ${ }^{87}$ ) \\
\hline & Congo Red & 150 & $96 \%$ & & \\
\hline \multirow[t]{2}{*}{ Pleurotus sp. MAK-II } & & & & NA & (Manavalan et al. ${ }^{88}$ ) \\
\hline & Remazol Brilliant Blue R & 150 & $72 \%$ & & \\
\hline $\begin{array}{l}\text { Marasmius cladophyllus UMAS } \\
\text { MS8 }\end{array}$ & Remazol Brilliant Blue R & 200 & $100 \%$ & 15 days & (Singh et al. ${ }^{89}$ ) \\
\hline \multicolumn{6}{|l|}{ Bacterial culture } \\
\hline $\begin{array}{l}\text { Pseudomonas extremorientalis } \\
\text { BUII8 }\end{array}$ & Congo red & 100 & $75 \%$ & $24 \mathrm{~h}$ & (Neifar et al. ${ }^{36}$ ) \\
\hline $\begin{array}{l}\text { Nesterenkonia lacusekhoensis } \\
\text { EMLA3 }\end{array}$ & Methyl red & 50 & $97 \%$ & $16 \mathrm{~h}$ & (Battacharaya et al..$^{90}$ ) \\
\hline Serratia liquefaciens & Azure-B & 100 & $90 \%$ & $48 \mathrm{~h}$ & (Haq et al. $\left.{ }^{91}\right)$ \\
\hline Bacillus aryabhattai DCI00 & $\begin{array}{l}\text { Coomassie Brilliant Blue } \\
\text { G-250 }\end{array}$ & 150 & $100 \%$ & $72 \mathrm{~h}$ & (Paz et al. $\left.{ }^{92}\right)$ \\
\hline \multirow{2}{*}{ Bacillus cereus RJVL 25 I4 } & Reactive Violet I 3 and & \multirow{2}{*}{100} & $88 \%$ & \multirow{2}{*}{ NA } & \multirow[t]{2}{*}{ (Gangavarapu et Ravuri, ${ }^{93}$ ) } \\
\hline & Reactive Blue 17| & & $87 \%$ & & \\
\hline Halomonas sp. strain A55 & Reactive Red 184 & 150 & $96 \%$ & $24 \mathrm{~h}$ & (Guadie et al. ${ }^{47}$ ) \\
\hline Staphylococcus sp. & Remazol & \multirow{2}{*}{100} & \multirow{2}{*}{$100 \%$} & \multirow{2}{*}{$12 \mathrm{~h}$} & \multirow{2}{*}{ (Kharthikeyan et al..$^{94}$ ) } \\
\hline K2204 & Brilliant Blue $\mathrm{R}$ & & & & \\
\hline
\end{tabular}

NA, Not Available 
Table 3 Decolorization of various azo dyes by bacterial consortia

\begin{tabular}{|c|c|c|c|c|c|}
\hline Strain & $\begin{array}{l}\text { Dye and } \\
\text { concentration (mg/L) }\end{array}$ & Class & $\begin{array}{l}\text { Condition (Temp. }\left({ }^{\circ} \mathrm{C}\right) \text {, } \\
\mathrm{pH} \text {, agitaion) }\end{array}$ & $\begin{array}{l}\text { Decolorization } \\
\text { (\%) and time (h) }\end{array}$ & References \\
\hline $\begin{array}{l}\text { Bacillus flexusNBN2, Bacillus } \\
\text { cereus AGP-03, Bacillus } \\
\text { cytotoxicusNVH 39l-98 and } \\
\text { Bacillus sp. LI0 }\end{array}$ & $\begin{array}{l}\text { Direct Blue I5I (DBI5I) } \\
\text { Direct Red 3I (DR 3I) } \\
200\end{array}$ & Double Azo & $36,9.5, \mathrm{NA}$ & 87,5 days & 95 \\
\hline Acinetobactersp. and Klebsiellasp. & $\begin{array}{l}\text { Reactive Orange } 16 \\
\text { Reactive Green } 19\end{array}$ & $\begin{array}{l}\text { Anionic single } \\
\text { azo } \\
\text { Double azo }\end{array}$ & 30,7 , static & 80,72 & 96 \\
\hline $\begin{array}{l}\text { Bacillus sp., Staphylococcus sp., } \\
\text { Escherichia sp., Enterococcus sp. } \\
\text { and Pseudomonas sp. }\end{array}$ & $\begin{array}{l}\text { Remazol Brilliant Violet } \\
\text { 5R (RBV5R), } 200\end{array}$ & Azo & $37,6.5$, microaerophilic & 100,18 & 73 \\
\hline $\begin{array}{l}\text { MIC (highest similarity to } \\
\text { Zobellellataiwanensisstrain AT I } \\
\text { and M2C (Bacillus pumilusstrain } \\
\text { HKG } 2 \text { I2) }\end{array}$ & Reactive green-19, 100 & Azo & $32,8.3, \mathrm{NA}$ & 97,24 & 97 \\
\hline $\begin{array}{l}\text { Microbacteriumsp., } \\
\text { Leucobacteralbus, Klebsiellasp. } \\
\text { and Staphylococcus arlettae }\end{array}$ & Disperse Red I & Azo & $\begin{array}{l}36,7 \text {, anaerobic-aerobic } \\
\text { reactor }\end{array}$ & 80,72 & 98 \\
\hline 15 different bacteria & Trypan Blue, 50 & Double azo & $30,7, \mathrm{NA}$ & 100,24 & 99 \\
\hline $\begin{array}{l}\text { Consortium GR: Proteus vulgaris } \\
\text { and Micrococcus glutamicus }\end{array}$ & $\begin{array}{l}\text { Green HE4BD and } \\
\text { many other reactive } \\
\text { dyes(Golden Yellow } \\
\text { HE4R, Orange 3R,Violet } \\
\text { 5R, Red ME4BL and Red } \\
\text { M2BN), } 50 \text { each) }\end{array}$ & $\begin{array}{l}\text { Reactive } \\
\text { double azo } \\
\text { (Reactive } \\
\text { double azo, } \\
\text { Reactive single } \\
\text { azo) }\end{array}$ & 37,8 , static, anoxic & 100,24 & 68 \\
\hline $\begin{array}{l}\text { Salmonella subterranea and } \\
\text { Paenibacilluspolymyxa }\end{array}$ & Reactive Blue 4, 300 & Anthraquinone & $35, \mathrm{NA}, \mathrm{NA}$ & $24,24 \mathrm{~h}$ & 101 \\
\hline $\begin{array}{l}\text { Pseudomonas pseudoalcaligenes, } \\
\text { Pseudomonas citronellolis and } \\
\text { Pseudomonas testosterone }\end{array}$ & Acid Orange 7, 100 & Azo & $37, \mathrm{NA}$, aerobic & 90,24 & 102 \\
\hline $\begin{array}{l}\text { Pseudomonas aeruginosa, Bacillus } \\
\text { flexusand Staphylococcus lentus }\end{array}$ & Acid blue 113,800 & Double azo & $\begin{array}{l}37,100 \mathrm{rpm} \text {, } \\
\text { isothermicbioreaction } \\
\text { calorimeter }\end{array}$ & $93.7,12-16$ & 103 \\
\hline $\begin{array}{l}\text { Pseudomonas putida and } \\
\text { Shewanellaoneidensis }\end{array}$ & Congo red, $0.5 \mathrm{mM}$ & Double azo & NA & 100,72 & 104 \\
\hline Twelve acclimatised consortia & Reactive Violet 5R, 100 & Single azo & 90,30 , shaking and static & 100,30 & 74 \\
\hline $\begin{array}{l}\text { Consortium : (aerobic granular } \\
\text { sludge) }\end{array}$ & $\begin{array}{l}\text { Reactive } \\
\text { Yellow, I } 5.5\end{array}$ & Single azo & $\begin{array}{l}\text { 30, I } 40 \text { rpm, } \\
\text { microaerophilic }\end{array}$ & 100,80 & 105 \\
\hline $\begin{array}{l}\text { Consortium of Purple Non-Sulfur } \\
\text { Bacteria (PNSB) }\end{array}$ & Reactive Red I59,500 & Azo & $\begin{array}{l}\text { Anaerobic sequencing } \\
\text { batch reactor (ANSBR) }\end{array}$ & $97.68 \pm 0.74$ & 106 \\
\hline $\begin{array}{l}\text { Pseudomonas, Arthrobacter, and } \\
\text { Rhizobium }\end{array}$ & Acid Orange 7, 200 & Azo & $\begin{array}{l}28 \pm 2,6.25 \pm 0.25 \text {, agitation, } \\
\text { Packed-Bed BAC reactor }\end{array}$ & 90,96 & 107 \\
\hline
\end{tabular}


Strain
Dye and concentration $(\mathrm{mg} / \mathrm{L})$
Class

\section{Condition (Temp. $\left({ }^{\circ} \mathrm{C}\right)$,} $\mathrm{pH}$, agitaion)
Decolorization

(\%) and time (h)
Actinobacteria, Bacteroidetes Proteobacteriaand Firmicutes

\section{Consortium (TJI),}

Aeromonascaviae,

Proteus mirabilis and

Rhodococcusgloberulus

\section{Providencia sp.}

SDSandPseudomonas

aeuroginosa strain $\mathrm{BCH}$

consortium BDN:Alcaligenes

sp., Bacillus sp., Escherichia sp.,

Pseudomonas sp., Providencia sp.,

Acinetobacter sp., Bacillus sp. and

Bacillus sp.

Halophilic consortium VN.I:

Pseudomonas fluorescens,

Enterobacteraerogenes,

Shewanella sp.,

Arthrobacternicotianae, Bacillus

beijingensisand Pseudomonas

aeruginosa

Pseudomonas sp., Brevibacillus sp. and two strains of Stenotrophomonas sp
Acid Brilliant Scarlet GR, 100

Acid Orange 7, 200

A mixture of reactive azo dyes: Red HE3B, Red HE8B, and Remazol Blue.

Mixture of reactive azo dyes, 300

Reactive Blue 220 (RB220), 2,500

dye mixture, 100
Azo

Azo

Azo

Azo

Microaerophilic fixed film reactor

30, 7, 150 r/min, Aerobic, batch processes

37, 7, microaerophilic

30,7

100,20

100,24 72

$37,6.5$, static, microaerophilic

100,12

90,16

108

Formazan $\quad 30,8$, static, $7 \% \mathrm{NaCl}$

100,30

110

Table 4 Methods used for evaluation of toxicity of azo dyes

\begin{tabular}{|c|c|c|}
\hline Methods & Organisms & References \\
\hline Genotoxicity & Allium cepa & 134 \\
\hline \multirow{3}{*}{ Mutagenicity } & Salmonella & 98 \\
\hline & E. coli & 135 \\
\hline & Allium cepa & 109 \\
\hline \multirow[t]{2}{*}{ Cytotoxicity } & MTT assay with human cell lines of keratinocytes ( $\mathrm{HaCat})$ & 103 \\
\hline & Human blood cells & 23 \\
\hline \multirow[t]{4}{*}{ Oxidative stress } & Allium cepa & 109 \\
\hline & Vigna radiata & 91 \\
\hline & Triticum aestivum & 136 \\
\hline & Phaseolus mungo & 136 \\
\hline \multirow[t]{5}{*}{ Phytotoxicity } & Zeamays L. & 137 \\
\hline & Sorghum vulgare & 138 \\
\hline & Phaseolus aureus & 110 \\
\hline & Lactuca sativa & 139 \\
\hline & Daphnia similis & 98 \\
\hline \multirow[t]{2}{*}{ Acute toxicity } & Hydra attenuata & 98 \\
\hline & Daphnia magna & 99 \\
\hline
\end{tabular}




\section{Other microbial consortia}

Conversely to decolorization by bacterial consortium, few reports are available on decolorization of dyes by yeast consortia and fungal consortia, especially on decolorization by biodegradation mechanism not by biosorption or bioaugmentation. Another approach is the synergistic action of fungal-bacterial consortium which provides an alternate way for efficient removal of various contaminants. Some reports indicated that fungi-bacteria co-cultures showed higher efficiency and stability ${ }^{11-114}$ to degrade the mixture of many kinds of macromolecule organics into small-molecule substances which can be further degraded or even mineralized by bacteria. ${ }^{65,115}$ In addition, few studies illustrate the ability of bacterium yeast consortium to treat TWWs. ${ }^{116}$ Apart from these approaches, A synergistic strategy occurred by involving plants such a plant-bacterial system using Glandularia pulchella and Pseudomonas monteilii $\mathrm{ANK}^{117}$ or plant consortia. ${ }^{118,119}$

\section{Mechanism of azo dye degradation}

It is very much important to understand well the mechanism by which azo dye decolorization is realized. Generally, biodegradation of azo dyes is achieved via two mechanisms either direct decolorization or indirect/mediated decolorization. Behind both mechanisms, enzymes are well involved to degrade recalcitrant compounds in the microbial system. ${ }^{120}$ Several reports demonstrate the degradation of complex organic substances by different enzymes including laccase, ${ }^{121,122}$ azoreductase, ${ }^{123,124}$ lignin peroxidase, ${ }^{6}$ NADH-DCIP reductase ${ }^{99}$ and hexane oxidase..$^{25}$ Among these families of enzymes, laccases and azoreductases have shown a great potential to decolorize a large range of known industrial dyes. Biodegradation of mainly azo dyes is due to the reduction of azo bonds $(-\mathrm{N}=\mathrm{N}-)$ by azoreductase enzymes under anaerobic condition. ${ }^{14}$ During this process, four electrons are transferred from electron donors to the electron acceptor (azo dye) in two stages at the azo linkage, resulting in dye decolorization and generation of colorless amines. ${ }^{10}$ Generated metabolites or aromatic amines are then further degraded aerobically or anaerobically. The role of laccase in asymmetric cleavage of azo dye was well reported in biodegradation of anthroquinone and azo dyes by a fungal strain Lentinus sp. ${ }^{125}$ The laccases from Brevibacillus sp. (Z1) $)^{126}$ and Anoxybacillus Gonensis P39 $9^{127}$ which are applied in removal of various azo dyes were purified and characterized. Under aerobic conditions, respiration may dominate utilization of NADH which inhibits the electron transfer from NADH to azo linkage. Thus, decolorization might be related to non-specific extracellular reactions occurring between reduced compounds generated by the anaerobic biomass. ${ }^{10}$ In anaerobic conditions, a low redox potential $(\leq 50 \mathrm{mV})$ causes the effective decolorization of the azo dyes decolorization and azoreductases were found to be oxygen sensitive and released extracellularly. ${ }^{128}$ In order to stimulate the removal process of dyes, researchers use redox mediators. Numerous studies proved that addition of redox mediators, such as synthetic electron carriers, anthraquinone-2-sulfonate or quinone compounds enhance significantly biodegradation of azo dyes. However, the high cost of quinone addition limited its usage. To make practical the application of bacteria-mediated decolorization, other redox mediators like activated carbon, carbon black and carbon nano tube were used.

\section{Analytical methods for evaluation of dye degradation mechanism}

Many analytical techniques are applied to identify the intermediates and aromatic amines generated during azo dye decolorization. UVVis analysis is a preliminary method by which products produced during biodegradation after incubation under anaerobic conditions were studied by following the change in the ultraviolet visible (UVVis) spectra. The dye decolorization was estimated by measuring the absorbance at $\lambda$ max of the dye using an UV-Vis spectrophotometer. ${ }^{129}$ For further detection of metabolites, Thin Layer Chromatography (TLC) and High Performance Thin Layer Chromatography (HPTLC) techniques are used. ${ }^{130}$ These methods give insights in numbers and types of metabolites generated. But for confirmation of the degradation of dye, HPLC has been largely used. ${ }^{10}$ Moreover, Fourier Transform Infrared Spectroscopy (FTIR) is also widely applied to check the removal of azo group from the azo dye and generation of new type of compounds. ${ }^{131}$ Another powerful techniques used for qualitative determination of metabolites are Gas ChromatographyMass Spectrometry (GC-MS) and Liquid Chromatography-Mass Spectrometry (LC-MS). The evaluation is occurred via molecular weights and structural information which is used further to propose the degradation pathway of the dye. At present, apart from these methods, advance technique, Nuclear Magnetic Resonance (NMR) is applied to get detailed quantitative study. ${ }^{132}$

\section{Microbial toxicity of azo dyes}

Microbial degradation of azo dyes generates intermediate organic compounds, aromatic amines, which are frequently reported to be mutagens and carcinogens. By-products generated may sometimes be even more toxic than the dyes themselves. ${ }^{21}$ Therefore, it is vital to evaluate the toxicity of both azo dyes and their metabolites. The toxicity caused by dye metabolites may not have the same effect on all levels of biological organizations. Basis on this fact, the studies on microbe-mediated dye detoxification are categorized into molecular, cellular, organismic and ecological levels. ${ }^{133}$ Molecular toxicity includes mutagenicity/genotoxicity which can be caused via oxidative DNA damage, micronuclei formation or chromosomal aberrations ${ }^{23}$ To determine this toxicological category, the widely used assays are Ames test, Comet assay, ${ }^{109}$ TUNEL assay and Allium cepa. Cellular level is the most investigated in the studies about toxic impacts on humans and organismic toxicity is used to identify toxicological impacts on model organisms including animals and plants. Conversely to these levels, ecotoxical studies are too complex. Thus, the main objective of ecotoxicity is to extrapolate and predict risk under laboratory conditions. More details about the different tests used for evaluation of toxicity azo dyes are mentioned in the Table 4. All reports ${ }^{98,103,109}$ using microbial consortium for TWWs treatment and degradation of azo dyes prove that it is an efficient approach to reduce significantly the toxicity of TWWs and azo dyes. ${ }^{140-150}$

\section{Conclusion}

TWWs pose a significant threat to the environment due to long term disposal. Physico-chemical techniques failed to decolorize TWWs in an efficient and economical manner. Bioremediation has been emerging approaches to tackle azo dye pollution. The overall 
evaluation of biological treatment suggests a positive outlook for microorganisms as a potential candidate for the removal of dyes from TWWs.

In this approach, co-cultivated microorganisms prove a significant efficiency in dye decolorization. Microbial consortia was found to be advantageous than pure cultures due to concerted metabolic activities of microbial community.

Although there are a large number of studies focusing on the field of dye decolorization, few studies ${ }^{75}$ have targeted the real effluent or TWWs treatment reference to azo dyes removal. Thus, more attention should be paid to commercialize and apply microbial consortia in TWWs treatment.

\section{Acknowledgments}

The authors acknowledge the financial support from the Tunisian Ministry of Higher Education and Scientific Research in the ambit of the laboratories' Projects BVBGR-LR11ES31 and MBA-LR03ES03.

\section{Conflicts of interest}

The authors declare that they have no competing interests.

\section{References}

1. Pandit AB, kumar JK. Clean water for developing countries: Annual review of chemical and biomolecular engineering. 2015;6:217-246.

2. Chekli L, Kim YP, Sherub P, et al. Evaluation of fertilizer-drawn forward osmosis for sustainable agriculture and water reuse in arid regions. Journal of environmental management. 2017;187:137-145.

3. Rajput RS, Pandey S, Bhadauria S. Status of water pollution in relation to industrialization in Rajasthan. Rev Environ Health. 2017;32(3):245-252.

4. Anastasopoulou A, Kolios A, Somorin T, et al. Conceptual environmental impact assessment of a novel self-sustained sanitation system incorporating a quantitative microbial risk assessment approach. Sci Total Environ. 2018;639:657-672.

5. Pensupa N, Leu SY, Hu Y, et al. Recent trends in sustainable textile waste recycling methods: Current situation and future prospects. Topics in Current Chemistry. 2017;375(5):76.

6. Zucca P, Neves CMB, Simões MMQ, et al. Immobilized lignin peroxidaselike metalloporphyrins as reusable catalysts in oxidative bleaching of industrial dyes. Molecules. 2016;21:E964.

7. Raman CD, Kanmani S. Textile dye degradation using nano zero valent iron: A review. J Environ Manage. 2016;177:341-355.

8. Weglarz-Tomczak E, Gorecki L. Azo dyes-biological activity and synthetic strategy. Chemik. 2012;66:1298-1307.

9. Prabakar D, Manimudi VT, Mathimani T, et al. Pretreatment technologies for industrial effluents: Critical review on bioenergy production and environmental concerns. J Environ Manage. 2018;218:165-180.

10. Singh SN. Microbial degradation of synthetic dyes in wastewaters Springer; 2014. 367 p. ISBN: 978-3-319-10942-8.

11. Ali H. Biodegradation of synthetic dyes-a review. Water, Air, \& Soil Pollution. 2010;213:251-273.

12. Cui D, Zhang H, He R, et al. The Comparative Study on the Rapid Decolorization of Azo, Anthraquinone and Triphenylmethane Dyes by Anaerobic Sludge. Int J Environ Res Public Health. 2016;13(11):1053.
13. Banat IM, Nigam P, Singh D, et al. Microbial decolorization of textile-dyecontaining effluents: a review. Bioresource technology. 1996;58(3):217-227.

14. Holkar CR, Jadhav AJ, Pinjari DP, et al. A critical review on textile wastewater treatments: possible approaches. $J$ Environ Manage. 2016;182:351-366.

15. Mahmood F, Shahid M, Hussain S, et al. Potential plant growth-promoting strain Bacillus sp. SR-2-1/1 decolorized azo dyes through NADHubiquinone:oxidoreductase activity. Bioresour Technol. 2017;235:176184

16. Dos Santos AB, Cervantes FJ, Van Lier JB. Review paper on current technologies for decolourisation of textile wastewaters: perspectives for anaerobic biotechnology. Bioresour Technol. 2007 ;98(12):2369-2385.

17. Pavko A. Fungal decolourization and degradation of synthetic dyes some chemical engineering aspects. Waste Water-Treatment and Reutilization. 2011:65-90.

18. Hunger K, Gregory P, Miederer P. Important chemical chromophores of dye classes. Industrial Dyes, Chemistry, Properties, Applications. 2004:13-112.

19. Saratale RG, Saratale GD, Chang JS, et al. Bacterial decolorization and degradation of azo dyes: a review. Journal of the Taiwan Institute of Chemical Engineers. 2011;42:138-157.

20. Rai HS, Bhattacharyya MS, Singh J, et al. Removal of dyes from the effluent of textile and dyestuff manufacturing industry: a review of emerging techniques with reference to biological treatment. Critical Reviews in Environmental Science and Technology. 2005;35(3) :219-238.

21. Solís M, Solís A, Pérez HI, et al. Microbial decolouration of azo dyes: a review. Process Biochemistry. 2012 ;47(12):1723-1748.

22. Mansour H, Boughzala O, Dridi D, et al. Textiles dyes as a source of wastewater contamination: screening of the toxicity and treatment methods. Journal of Water Science. 2011;24(3):209-238.

23. Bafana A, Devi SS, Chakrabarti T. Azo dyes: past, present and the future. Environmental Reviews. 2011;19:350-371.

24. Saratale RG, Saratale GD, Kalyani DC, et al. Enhanced decolorization and biodegradation of textile azo dye Scarlet $\mathrm{R}$ by using developed microbial consortium-GR. Bioresour Technol. 2009;100(9):2493-2500.

25. Dafale N, Wate S, Meshram S, et al. Bioremediation of wastewater containing azo dyes through sequential anaerobic-aerobic bioreactor system and its biodiversity. Environmental Reviews. 2010;18:21-36.

26. Maron DM, Ames BN. Revised methods for the Salmonella mutagenicity test. Mutat Res. 1983;113(3-4):173-215.

27. Yang RT. Gas separation by adsorption processes. ButterworthHeinemann, Oxford; 2013.

28. Chung KT. Azo dyes and human health: A review. J Environ Sci Health $C$ Environ Carcinog Ecotoxicol Rev. 2016;34(4):233-261.

29. Soares Graça MB, Costa-Ferreira M, De amorim MT. Decolorization of an anthraquinone-type dye using a laccase formulation. Bioresour Technol. 2001;79:171-177.

30. Sharma DK, Saini HS, Singh M, et al. Biological treatment of textile dye Acid violet $\square 17$ by bacterial consortium in an up $\square$ flow immobilized cell bioreactor. Lett Appl Microbiol. 2004;38(5):345-350.

31. Cheriaa J, Khaireddine M, Rouabhia M, et al. Removal of triphenylmethane dyes by bacterial consortium. The Scientific World Journal. 2012. 
32. Ahmad A, Mohd-Setapar SH, Chuong CS, et al. Recent advances in new generation dye removal technologies: novel search for approaches to reprocess wastewater. RSC Advances. 2015;5:30801-30818.

33. Robinson T, Mcmullan G, Marchant R, et al. Remediation of dyes in textile effluent: a critical review on current treatment technologies with a proposed alternative. Bioresour Technol. 2001;77(3):247-255.

34. Jadhav JP, Parshetti GK, Kalme SD. et al. Decolourization of azo dye methyl red by Saccharomyces cerevisiae MTCC 463. Chemosphere. 2007;68(2):394-400.

35. Neifar M, Maktouf S, Ghorbel RE, et al. Extremophiles as source of novel bioactive compounds with industrial potential. In: Gupta V K, Tuohy MG, O'Donovan A, Lohani M, editors. Biotechnology of bioactive compounds: sources and applications. Wiley, Hoboken; 2015:245-268.

36. Neifar M, Chouchane H, Mahjoubi M, et al. Pseudomonas extremorientalis BU118: a new salt-tolerant laccase-secreting bacterium with biotechnological potential in textile azo dye decolourization. 3 Biotech. 2016;6,107.

37. Kadam AA, Kulkarni AN, Lade HS, et al. Exploiting the potential of plant growth promoting bacteria in decolorization of dye Disperse Red 73 adsorbed on milled sugarcane bagasse under solid state fermentation. International Biodeterioration \& Biodegradation. 2013;86:1-8.

38. Mahmood F, Shahid M, Hussain S. Potential plant growth-promoting strain Bacillus sp. SR-2-1/1 decolorized azo dyes through NADHubiquinone:oxidoreductase activity. Bioresour Technol. 2017;235:176184.

39. Van Der Zee F, Villaverde S. Combined anaerobic-aerobic treatment of azo dyes-a short review of bioreactor studies. Water Res. 2005;39:14251440

40. Mahmood S, Khalid A, Arshad M, et al. Detoxification of azo dyes by bacterial oxidoreductase enzymes. Crit Rev Biotechnol. 2015;36(4):639651.

41. Neifar M, Chouchane H, Masmoudi AS, et al. Biotechnological potential of extremophilic laccases. In: Harris A, editor. Laccase: Applications, Investigations and Insights. New York: Nova Science Pub; 2017:125-142.

42. Khan R, Bhawana P, Fulekar MH. Microbial decolorization and degradation of synthetic dyes: a review. Rev Environ Sci Biotechnol. 2013;12(1):75-97.

43. Wuhrmann K, Mechsner KL, Kappeler TH. Investigation on rateDetermining factors in the microbial reduction of azo dyes. European journal of applied microbiology and biotechnology. 1980;9(4):325-338.

44. Surwase SV, Deshpande KK, Phugare SS, et al. Biotransformation studies of textile dye Remazol Orange 3R. 3 Biotech. 2013;3(4):267-275.

45. Junior JCV, Cavalcanti DL, Da Silva CAA, et al. Decolorization of Black B azo dye by Pseudomonas aeruginosa. Int J Curr Microbiol App Sci. 2015;4:720-728.

46. Asad S, Amoozegar MA, Pourbabaee AA, et al. Decolorization of textile azo dyes by newly isolated halophilic and halotolerant bacteria. Bioresource technology. 2007;98:2082-2088.

47. Guadie A, Gessesse A, Xia S. Halomonas sp. Strain A55, a novel dye decolorizing bacterium from dye-uncontaminated Rift Valley Soda Lake. Chemosphere. 2018;206:59-69.

48. Chen BY, Lin KW, Wang YM, et al. Revealing interactive toxicity of aromatic amines to azo dye decolorizer Aeromonas hydrophila. Journal of hazardous materials. 2009;166:187-194.

49. Singh S, Pakshirajan K, Daverey A. Enhanced decolourization of Direct Red- 80 dye by the white rot fungus Phanerochaete chrysosporium employing sequential design of experiments. Biodegradation. 2010;21(4):501-511.
50. Sumandono T, Saragih H, Migirin Watanabe T, et al. Decolorization of Remazol Brilliant Blue R by new isolated white rot fungus collected from tropical rain forest in East Kalimantan and its ligninolytic enzymes activity. Procedia Environmental Sciences. 2015;28:45-51.

51. Eichlerová I, Homolka L, Lisá L, et al. Orange G and Remazol Brilliant Blue $\mathrm{R}$ decolorization by white rot fungi Dichomitus squalens, Ischnoderma resinosum and Pleurotus calyptratus. Chemosphere. 2005;60(3):398-404.

52. Kalpana D, Shim JH, Oh BT, et al. Bioremediation of the heavy metal complex dye Isolan Dark Blue 2SGL-01 by white rot fungus Irpex lacteus. J Hazard Mater. 2011;198:198-205.

53. Si J, Cui BK, Dai YC. Decolorization of chemically different dyes by white-rot fungi in submerged cultures. Annals of Microbiology. 2013;63:1099-1108

54. Lam DM, Thi Chien T. Isolation, selection and identification of laccaseproducing fungal strains and its dye decolorization ability. Chemical and Biological Sci. 2013;58:132-138.

55. Neifar M, Jaouani A, Ellouze-Ghorbel R. Purification, characterization and decolourization ability of Fomes fomentarius laccase produced in solid medium. Journal of Molecular Catalysis B: Enzymatic. 2010;64(12):68-74.

56. Anastasi A, Parato B, Spina F, et al. Decolourisation and detoxification in the fungal treatment of textile wastewaters from dyeing processes. $N$ Biotechnol. 2011;29:38-45.

57. El-Rahim WMA, Moawad H, Abdel Azeiz AZ, et al. Optimization of conditions for decolorization of azo-based textile dyes by multiple fungal species. Journal of biotechnology. 2017;260:11-17.

58. Jin XC, Liu GQ, Xu ZH, et al. Decolorization of a dye industry effluent by Aspergillus fumigatus XC6. Appl Microbiol Biotechnol. 2007;74(1):239243.

59. Charumathi D, Das N. Packed bed column studies for the removal of synthetic dyes from textile wastewater using immobilised dead $C$ tropicalis. Desalination. 2012;285:22-30.

60. Martins MAM, Cardoso MH, Queiroz MJ, et al. Biodegradation of azo dyes by the yeast Candida zeylanoides in batch aerated cultures. Chemosphere. 1999;38(11):2455-2460.

61. Tan L, Ning S, Zhang X, et al. Aerobic decolorization and degradation of azo dyes by growing cells of a newly isolated yeast Candida tropicalis TL-F1. Bioresour Technol. 2013;138:307-313.

62. Ademakinwa AN, Agboola FK. Bioremediation of textile dye solutions, textile dye mixtures and textile effluents by laccase from Aureobasidium pullulans (de Bary) G. Arnaud (1918) (Fungi: Ascomycota). Brazilian Journal of Biological Sciences. 2015;2:253-262.

63. Vitor V, Corso CR. Decolorization of textile dye by Candida albicans isolated from industrial effluents. $J$ Ind Microbiol Biotechnol. 2008;35(11):1353-1357.

64. Dilarri G, Corso CR. Saccharomyces cerevisiae immobilized onto crosslinked chitosan beads: application of a novel material for the removal of dye toxicity. Environ Technol. 2018;39(14):1851-1867.

65. He M, Tan L, Ning S, et al. Performance of the biological aerated filter bioaugmented by a yeast Magnusiomyces ingens LH-F1 for treatment of Acid Red B and microbial community dynamics. World J Microbiol Biotechnol. 2017;33(2):39.

66. Meehan C, Banat IM, Mcmullan G. Decolorization of Remazol Black-B using a thermotolerant yeast, Kluyveromyces marxianus IMB3. Environ Int. 2000;26:75-79.

67. Khan R, Khan Z, Nikhil B, et al. Azo dye decolorization under microaerophilic conditions by a bacterial mixture isolated from anthropogenic dye-contaminated soil. Bioremediation journal. 2014;18(2):147-157. 
68. Saratale RG, Saratale GD, Chang JS, et al. Decolorization and biodegradation of reactive dyes and dye wastewater by adeveloped bacterial consortium. Biodegradation. 2010;21(6):999-1015.

69. Kumari S, Naraian R. Decolorization of synthetic brilliant green carpet industry dye through fungal co-culture technology. J Environ Manage. 2016;180:172-179.

70. Liu Y, Ding M, Ling W. A three-species microbial consortium for power generation. Energy Environ Sci. 2017.

71. Chattaraj S, Johnson J, Madamwar D. Biotransformation of mixture of dyes by enriched bacterial consortium ASD. Desalination and Water Treatment. 2016;57(45):21585-21597.

72. Balapure K, Bhatt N, Madamwar D. Mineralization of reactive azo dyes present in simulated textile waste water using down flow microaerophilic fixed film bioreactor. Bioresource technology. 2015;175:1-7.

73. Shah B, Jain K, Jiyan IH, et al. Microaerophilic Symmetric Reductive Cleavage of Reactive Azo Dye-Remazole Brilliant Violet 5R by Consortium VIE6: Community Synergism. Applied biochemistry and biotechnology. 2016;180(6):1029-1042.

74. Ratho J, Archana G. Molecular fingerprinting of bacterial communities in enriched azo dye (Reactive Violet 5R) subterranean native subterranean bacterial consortia. Bioresour Technol. 2013;142:436-444.

75. Imran M, Crowley DE, Khalid A, et al. Microbial biotechnology for decolorization of textile wastewaters. Reviews in Environmental Science and Bio/Technology. 2015;14(1):73-92.

76. Moosvi S, Keharia H, Madamwar D. Decolourization of textile dye Reactive Violet 5 by a newly isolated bacterial consortium RVM 11.1. World Journal of Microbiology \& Biotechnology. 2005;21:667-672.

77. Lade H, Kadam A, Paul D, et al. A Low-Cost Wheat bran medium for biodegradation of the benzidine-based carcinogenic dye Trypan Blue using a microbial consortium. Int J Environ Res Public Health. 2015;12:34803505 .

78. Tan L, Ning S, Wang Y, et al. Influence of dye type and salinity on aerobic decolorization of azo dyes by microbial consortium and the community dynamics. Water Sci Technol. 2012;65(8):1375-1382.

79. Netzker T, Flak M, Krespach MKC, et al. Microbial interactions trigger the production of antibiotics. Curr Opin Microbiol. 2018;45:117-123.

80. Alvarez LH, Valdez-Espinoza R, García-Reyes RB, et al. Decolorization and biogas production by an anaerobic consortium: effect of different azo dyes and quinoid redox mediators. Water Science and Technology. 2015;72(5):794-801.

81. Alvarez LH, Meza-Escalante ER, Gortáres-Moroyoqui P. Influence of redox mediators and salinity level on the (bio) transformation of Direct Blue 71: kinetics aspects. Journal of environmental management. $2016 ; 183: 84-89$.

82. Deivasigamani C, Das N. Biodegradation of Basic Violet 3 by Candida krusei isolated from textile wastewater. Biodegradation. 2011;22(6):11691180 .

83. Martorell MM, Rosales S, María M, et al. Optimization and mechanisms for biodecoloration of a mixture of dyes by Trichosporon akiyoshidainum HP 2023. Environ Technol. 2018;39(24):3169-3180.

84. He Xl, Song C, Li Yy, et al. Efficient degradation of Azo dyes by a newly isolated fungus Trichoderma tomentosum under non-sterile conditions. Ecotoxicol Environ Saf. 2018;150:232-239.

85. Vats A, Mishra S. Decolorization of complex dyes and textile effluent by extracellular enzymes of Cyathus bulleri cultivated on agro-residues/ domestic wastes and proposed pathway of degradation of Kiton blue A and reactive orange 16. Environ Sci Pollut Res Int. 2017;24(12):11650-11662.

86. Yang SO, Sodaneath H, Lee JI, et al. Decolorization of acid, disperse and reactive dyes by Trametes versicolor CBR43. J Environ Sci Health A Tox Hazard Subst Environ Eng. 2017;52(9):862-872.

87. Sodaneath H, Lee JI, Yang SO, et al. Decolorization of textile dyes in an air-lift bioreactor inoculated with Bjerkandera adusta OBR105. J Environ Sci Health A Tox Hazard Subst Environ Eng. 2017;52(11):1099-1111.

88. Manavalan A, Manavalan T, Murugesan K, et al. Characterization of a solvent, surfactant and temperature-tolerant laccase from Pleurotus sp. MAK-II and its dye decolorizing property. Biotechnol Lett. 2015;37(12):2403-2409.

89. Sing NN, Husaini A, Zulkharnain A, et al. Decolourisation capabilities of ligninolytic enzymes produced by Marasmius cladophyllus UMAS MS8 on remazol brilliant blue $\mathrm{r}$ and other azo dyes. BioMed research international. 2017.

90. Bhattacharya A, Goyal N, Gupta A. Degradation of azo dye methyl red by alkaliphilic, halotolerant Nesterenkonia lacusekhoensis EMLA3: application in alkaline and salt-rich dyeing effluent treatment. Extremophiles. 2017;21:479-490.

91. Haq I, Raj A, Markandeya. Biodegradation of Azure-B dye by Serratia liquefaciens and its validation by phytotoxicity, genotoxicity and cytotoxicity studies. Chemosphere. 2018;196:58-68.

92. Paz A, Carballo J, Pérez MJ, et al. Biological treatment of model dyes and textile wastewaters. Chemosphere. 2017;181:168-177.

93. Gangavarapu VL, Ravuri JM. Decolourisation of Reactive Violet 13 and Reactive Blue 171 by Bacillus cereus RJVL 2514 isolated from dye contaminated soils. International Journal of Environmental Sciences. 2016;7:30-39.

94. Karthikeyan V, Kumar MA, Mohanapriya P, et al. Biodegradation of Remazol Brilliant Blue R using isolated bacterial culture (Staphylococcus sp. K2204). Environmental technology. 2017;39(22):1-8.

95. Lalnunhlimi S, Krishnaswamy V. Decolorization of azo dyes (Direct Blue 151 and Direct Red 31) by moderately alkaliphilic bacterial consortium. Braz J Microbiol. 2016;47:39-46.

96. Meerbergen K, Willems KA, Dewil R, et al. Isolation and screening of bacterial isolates from wastewater treatment plants to decolorize azo dyes. J Biosci Bioeng. 2018;125(4):448-456.

97. Das A, Mishra S. Removal of Textile dye Reactive Green-19 using bacterial Consortium: Process optimization using response surface methodology and kinetics study. Journal of Environmental Chemical Engineering. 2017;5(1):612-627.

98. Franciscon E, Mendonca D, Seber S. Potential of a bacterial consortium to degrade azo dye Disperse Red 1 in a pilot scale anaerobic-aerobic reactor. Process Biochemistry. 2015;50(5):816-825.

99. Lade H, Kadam A, Paul D. et al. Biodegradation and detoxification of textile azo dyes by bacterial consortium under sequential microaerophilic/ aerobic processes. EXCLI J. 2015;14:158-174.

100. Tony BD, Goyal D, Khanna S. Decolorization of textile azo dyes by aerobic bacterial consortium. International Biodeterioration \& Biodegradation. 2009;63(4):462-469.

101. Watanapokasin RY, Boonyakamol A, Sukseree S, et al. Hydrogen production and anaerobic decolorization of wastewater containing Reactive Blue 4 by a bacterial consortium of Salmonella subterranean and Paenibacillus polymyxa. Biodegradation. 2009;20:(3):411-418.

102. Barsing P, Tiwari A, Joshi T, et al. Application of a novel bacterial consortium for mineralization of sulphonated aromatic amines. Bioresource technology. 2011;102:765-771.

103. Shanmugam B, Mahadevan S. Metabolism and biotransformation of azo dye by bacterial consortium studied in a bioreaction calorimeter. Bioresour Technol. 2015;196:500-508. 
104. Wang VB, Chua SL, Cai Z. A stable synergistic microbial consortium for simultaneous azo dye removal and bioelectricity generation. Bioresour Technol. 2014;155:71-76.

105. Sarvajith M, Reddy GKK, Nancharaiah YV. Textile dye biodecolourization and ammonium removal over nitrite in aerobic granular sludge sequencing batch reactors. J Hazard Mater. 2018;342:536-543.

106. Srisuwun A, Tantiwa N, Kuntiya A, et al. Decolorization of Reactive Red 159 by a consortium of photosynthetic bacteria using an anaerobic sequencing batch reactor (AnSBR). Prep Biochem Biotechnol. 2018;48(4):303-311.

107. Ruiz-Arias A, Juárez-Ramírez C, de los Cobos-Vasconcelos D. Aerobic biodegradation of a sulfonated phenylazonaphthol dye by a bacterial community immobilized in a multistage packed-bed BAC reactor. Appl Biochem Biotechnol. 2010;162(6):1689-1707.

108. Joshi T, Iyengar L, Singh K, et al. Isolation, identification and application of novel bacterial consortium TJ-1 for the decolourization of structurally different azo dyes. Bioresour Technol. 2008;99(15):7115-7121.

109. Phugare SS, Kalyani DC, Patil AV, et al. Textile dye degradation by bacterial consortium and subsequent toxicological analysis of dye and dye metabolites using cytotoxicity, genotoxicity and oxidative stress studies. $J$ Hazard Mater. 2011;186:713-723.

110. Patel VR, Bhatt N. Isolation, development and identification of salt-tolerant bacterial consortium from crude-oil-contaminated soil for degradation of di-azo dye Reactive Blue 220. Water Sci Technol. 2015;72(2):311-321.

111. Gou M, Qu Y, Zhou J, et al. Azo dye decolorization by a new funga isolate, Penicillium sp. QQ and fungal-bacterial cocultures. J Hazard Mater. 2009;170(1):314-319.

112. Kadam AA, Telke AA, Jagtap SS. Decolorization of adsorbed textile dyes by developed consortium of Pseudomonas sp. SUK1 and Aspergillus ochraceus NCIM-1146 under solid state fermentation. Journal of Hazardous Materials. 2011;189(1-2):486-494.

113. Jusoh N, Mohd Ruseli SNN, Firdaus Badri M, et al. Biodecolourisation of Methyl Red Dye by Bacterial-Fungal Consortium. Chemical Engineering Transactions. 2017;56:1537-1542.

114. Yuan X, Zhang X, Chen X, et al. Synergistic degradation of crude oil by indigenous bacterial consortium and exogenous fungus Scedosporium boydii. Bioresource technology. 2018;264:190-197.

115. Lade H, Kadam A, Paul D, et al. Exploring the potential of fungalbacterial consortium for low-cost biodegradation and detoxification of textile effluent. Archives of environmental protection. 2016;42:12-21.

116. Kurade MB, Waghmode TR, Patil SM, et al. Monitoring the gradual biodegradation of dyes in a simulated textile effluent and development of a novel triple layered fixed bed reactor using a bacterium-yeast consortium. Chemical Engineering Journal. 2017;307:1026-1036.

117. Kabra Akhil N, Khandare RV, Govindwar SP. Development of a bioreactor for remediation of textile effluent and dye mixture: a plant-bacterial synergistic strategy. Water Res. 2013;47:1035-1048.

118. Kabra AN, Khandare RV, Waghmode TR. Et al. Differential fate of metabolism of a sulfonated azo dye Remazol Orange 3R by plants Aster amellus Linn.,Glandularia pulchella (Sweet) Tronc. and their consortium. J Hazard Mater. 2011;190(1-3):424-431.

119. Kadam SK, Chandanshive VV, Rane NR. Phytobeds with Fimbristylis dichotoma and Ammannia baccifera for treatment of real textile effluent: An in situ treatment, anatomical studies and toxicity evaluation. Environmental research. 2018;160:1-11.
120. Singh RL, Singh PK, Singh RP. Enzymatic decolorization and degradation of azo dyes-A review. International Biodeterioration \& Biodegradation. 2015;104:21-31.

121. Liu H, Cheng Y, Du B. Overexpression of a novel thermostable and chloride-tolerant laccase from Thermus thermophilus SG0. 5JP17-16 in Pichia pastoris and its application in synthetic dye decolorization. PloS One. 2015;10:e119833.

122. Verma A, Dhiman K, Shirkot P. Biodegradation of Malachite Green by Extracellular Bacterial Laccase and Its Phytotoxicity Studies. Int J Pure App Biosci. 2017;5:913-922.

123. Chengalroyen MD, Dabbs ER. The microbial degradation of azo dyes: minireview. World J Microbiol Biotechnol. 2013;29(3):389-399.

124. Karatay S, Kiliç NK, Dönmez G. Removal of Remazol Blue by azoreductase from newly isolated bacteria. Ecological Engineering. 2015;84:301-304

125. Hsu CA, Wen TN, Su YC, et al. Biological Degradation of Anthroquinone and Azo Dyes by a Novel Laccase from Lentinus sp. Environ Sci Technol. 2012;46(9):5109-5117.

126. Bozoglu C, Adiguzel A, Nadaroglu H, et al. Purification and Characterization of Laccase from newly isolated Thermophilic Brevibacillus sp. (Z1) and its applications in removal of Textile Dyes. Res J Biotech. 2013;8:56-66.

127. Yanmis D, Adiguzel A, Nadaroglu $H$, et al. Purification and characterization of laccase from thermophilic Anoxybacillus gonensis P39 and its application of removal textile dyes. Rom Biotechnol Lett. 2016;21(3):11485-11496.

128. Prasad ASA, Kumar G, Thomas DM. Microbial decolorization of azo dyes -a mini review. Bull Chem Pharma Res. 2017;1:30-39.

129. Cui D, Li G, Zhao M, et al. Decolourization of azo dyes by a newly isolated Klebsiella sp. strain Y3, and effects of various factors on biodegradation. Biotechnol Biotechnol Equip. 2014;28(3):478-486.

130. Mohana S, Shrivastava S, Divecha J, et al. Response surface methodology for optimization of medium for decolorization of textile dye Direct Black 22 by a novel bacterial consortium. Bioresour Technol. 2008;99(3):562569.

131. Shanmugam BK, Easwaran SN, Lakra R, et al. Metabolic pathway and role of individual species in the bacterial consortium for biodegradation of azo dye: a biocalorimetric investigation. Chemosphere. 2017;188:81-89.

132. Ayed L, Khelifi E, Ben Jannet H, et al. Response surface methodology for decolorization of azo dye Methyl Orange by bacterial consortium: Produced enzymes and metabolites characterization. Chemical Engineering Journal. 2010;165(1):200-208.

133. Rawat D, Mishra V, Sharma RS. Detoxification of azo dyes in the context of environmental processes. Chemosphere. 2016;155:591-605.

134. Hemachandra CK, Pathiratne A. Combination of physico-chemical analysis, Allium cepa test system and Oreochromis niloticus erythrocyte based comet assay/nuclear abnormalities tests for cyto-genotoxicity assessments of treated effluents discharged from textile industries. Ecotoxicol Environ Saf. 2016;131:54-64.

135. Feng J, Cerniglia CE, Chen H. Toxicological significance of azo dye metabolismby human intestinal microbiota. Front Biosci (Elite Ed). 2018;4:568-586.

136. Patil PS, Shedbalkar UU, Kalyani DC. Et al. Biodegradation of reactive blue 59 by isolated bacterial consortium PMB11. J Ind Microbiol Biotechnol. 2008;35(10):1181-1190. 
137. Mahmood R, Sharif F, Ali S. Enhancing the Decolorizing and Degradation Ability of Bacterial Consortium Isolated from Textile Effluent Affected Area and Its Application on Seed Germination. Scientific World Journal. 2015;2015:628195.

138. Lade H, Kadam A, Paul D. et al. Decolorization and biodegradation of textile azo dye disperse red 78 by providencia rettgeri strain HSL1. 2014;1(1).

139. Ceretta MB, Durruty I, Orozco AMF, et al. Biodegradation of textile wastewater: enhancement of biodegradability via the addition of cosubstrates followed by phytotoxicity analysis of the effluent. Water Sci Technol. 2018;2017(2):516-526.

140. Vajnhandl S, Valh JV. The status of water reuse in European textile sector. J Environ Manage. 2014;41:29-35.

141. Dasgupta J, Sikder J, Chakraborty S, et al. Remediation of textile effluents by membrane based treatment techniques: a state of the art review. Journal of environmental management. 2015;147 :55-72.

142. U.S. Environmental Protection Agency.

143. Yusuff RO, Sonibare JA. Characterization of textile industries' effluents in Kaduna, Nigeria and pollution implications. Global Nest:The International Journal. 2004;6(3):212-221.

144. Kaushik G, Gopal M, Thakur IS. Evaluation of performance and community dynamics of microorganisms during treatment of distillery spent wash in a three stage bioreactor. Bioresour Technol. 2010;101:42964305 .
145. Topaç FO, Dindar E, Uçaroğlu S. Effect of a sulfonated azo dye and sulfanilic acid on nitrogen transformation processes in soil. J Hazard Mater. 2009;170:1006-1013.

146. Yaseen M, Aziz MZ, Komal A. Management of textile wastewater for improving growth and yield of field mustard (Brassica campestris L.). Int J Phytoremediation. 2017;19:798-804.

147. Chen BY. Toxicity assessment of aromatic amines to Pseudomonas luteola: Chemostat pulse technique and dose-response analysis. Process Biochemistry. 2006;41:1529-1538

148. De Lima ROA, Bazo AP, Salvadori DF, et al. Mutagenic and carcinogenic potential of a textile azo dye processing plant effluent that impacts a drinking water source. Mutat Res. 2007;626(1-2):53-60.

149. Ben Mansour H, Ayed-Ajmi Y, Mosrati R, et al. Acid violet 7 and its biodegradation products induce chromosome aberrations, lipid peroxidation, and cholinesterase inhibition in mouse bone marrow. Environ Sci Pollut Res Int. 2010;17(7):1371-1378.

150. Wackerow-kouzova ND. Isolation and study of azobenzene-transforming soil bacteria. Applied Biochemistry and Microbiology. 2005;41(2):162164 